\title{
A Participatory Approach to the Development of Centralized Information Systems
}

\author{
HOWAT NOBLE*, ROBERT A. STOLL**, IAN S. CALVERT***
}

In this article, we address the development and implementation of centralized information systems in the public sector. More specifically, we are concerned with implementation of such systems where a central governmental agency is collecting information from a number of similar institutions; for example, hospitals and colleges.

It is our contention that the numerous problems traditionally associated with such systems often stem from the lack of a realistic participatory approach in the development and implementation of the system. This article discusses the participatory approach to the development and implementation of such a system - the Ontario College Information System (OCIS), a computer-based information system containing information on

Ontario's twenty-two Colleges of Applied Arts and Technology.

The remainder of this article consists of four sections, namely:

A. Information Systems in the Public Sector - This section outlines needs for centralized information systems, the people interacting with such systems and some common problems which have been associated with centralized systems.

B. Ontario Before the Ontario College Information System (OCIS) - This section provides an overview of the major operational structures involved in the information exchange between the Ontario Government and the Colleges, the Boards of Governors, the Council of Regents, the Ministry and the colleges. As well, we review the information system which existed prior to OCIS.

C. The Participatory Aspects of OCIS - This section outlines the organizational structures, some created specifically to promote the participatory development of information exchange, involved in the development of OCIS. In describing these structures we discuss their membership, their responsibilities, their organizational interactions. As well, this section discusses the assumptions arising from the 'participatory' structures-assumptions which controlled the OCIS development activities.

D. Present Status of OCIS - This section reviews the actual components of OCIS which have been, are being and will be developed. As well, this section outlines some of the perceived advantages of our participatory approach.

\footnotetext{
* Chairman - Ministry Task Force on College Planning, Ministry of Colleges and Universities.

** Senior Project Manager, Special Projects Office, MCU.

*** President, Ian Calvert and Associates Ltd.
} 
E. Summary - This section summarizes the participatory experience to date.

We would emphasize that this article does not deal in detail with the software components and information content of OCIS. An OCIS system related to a specific type of college information will be discussed in a subsequent article.

\section{RÉSUMÉ}

Il s'agit, dans la présente étude, de l'élaboration et de la mise en oeuvre des systèmes d'information centralisés dans le secteur public. Plus précisément, nous nous préoccupons de l'exécution de tels systèmes là où une agence gouvernementale centrale se charge de la cueillette d'information pour plusieurs institutions semblables, par exemple, les hôpitaux et les collèges.

Nous soutenons que les nombreux problèmes associés traditionnellement avec de tels systèmes sont dérivés souvent de l'absence d'approche réaliste de participation dans l'élaboration et la mise en oeuvre du système. Cette étude discute de l'approche de participation pour l'élaboration et la mise en oeuvre du système appelé le Ontario College Information System (OCIS) - un système de données informatisées sur les 22 collèges de lettres et de technologie appliquées en Ontario.

La suite de l'étude comprend quatre parties:

$A$. Les systèmes d'information dans le secteur public. Cette partie étudie les besoins qui encouragent le développement des systèmes d'information centralisés, les personnes et les systèmes qui agissent les uns sur les autres et quelques uns des problèmes communs qui ont été associées aux systèmes centralisés.

$B$. L'Ontario d'avant le OCIS. Cette partie fournit une vue d'ensemble des structures clefs utilisées pour réaliser les échanges d'information entre le gouvernement de l'Ontario et les conseils d'administration des universités ainsi que ceux des collèges, entre le ministère et les collèges. De plus, nous revoyons le système d'information qui existait avant l'OCIS.

C. Les aspects de participation de l'OCIS. Cette partie trace les structures organisatrices, quelques unes créés expressément pour promouvoir l'élaboration de participation dans les échanges d'information dont il est question pour le développement de l'OCIS. Notre description de ces structures jette de la lumière sur leurs adhérents, les responsabilités de ces derniers et comment ils agissent les uns sur les autres. De plus, cette partie discute des présomptions suscitées par des structures de participation. Ces présomptions sont à la base des activités de l'élaboration de l'OCIS.

D. Statut à l'heure actuelle de l'OCIS. Cette partie retrace les composants de l'OCIS. C'est-à-dire ceux qui ont été développé, le sont et le seront. De plus, cette partie fait valoir quelques uns des aspects avantageux, qui se sont révélés, de l'approche de participation.

E. Résumé. Cette partie fait le point en ce qui concerne l'expérience de participation jusqu'à maintenant.

Nous tenons à préciser que cette étude ne traite pas en détail des composants du "software" ni du contenu de l'information de l'OCIS. Lors d'une publication ultérieure, 
il sera question d'un système tel qu'OCIS mais ayant rapport à un type spécifique de données sur les collèges.

\section{INFORMATION SYSTEMS IN THE PUBLIC SECTOR}

\section{Need for Centralized Systems}

All levels of governments face a common challenge: how to make effective use of public monies in the supply of essential services such as education and health. The information required to make decisions assuring effective use of the taxpayers' dollars should be based on data, which must often be obtained from semi-autonomous agencies or institutions such as hospitals, universities and colleges. Obtaining such information can lead to a potential conflict between the freedom of such institutions to operate within their defined mandates and the government's need for detailed comparative data concerning their operations.

A government's needs for an agency's or institution's information can normally be satisfied by current, historical and projected information on:

- the demand for the service; for example, how many people wanted to attend a specific college, how many people sought admittance to a hospital;

- the extent of the service provided; for example, how many students were admitted to a university;

- the nature of the service provided; for example, how many patients had what kinds of hospital care;

- the cost of the service in absolute and unit amounts; for example, how much was the operating budget of a university, what was the cost of graduating a student in veterinary medicine;

- the results of the service being (or not being) provided; for example, how many college graduates obtained jobs.

The data required to provide the above types of information has certain characteristics. These characteristics have logically led to the development of centralized information systems. They include:

- the data is voluminous and is required in many different formats and levels of aggregation, characteristics which lend themselves to computerization;

- the data source is normally decentralized, the information need predominantly centralized. This diverse source/application of data leads to systems becoming highly centralized;

- data must be usable in a way which permits valid inter-institution comparison; for example, it must be collected according to one common set of definitions, a task which is logically suited to central coordination.

The possible applications for centralized, computer-based information systems are numerous. However, the implementation of such systems has proved problematic in the past. 


\section{People and Information Systems}

It is all too simple to overlook the human elements associated with any centralized system. These human elements can be grouped into the following categories:

- users: those who require quantitative information on the operation of the institutions. These people normally are present in the central government agency. However, they may be from the institutions or other external organization, for example, national statistical groups;

- suppliers: those responsible for the collection, submission and validation of the information required from the institution. These people are resident in the individual institutions;

- operators: those, generally involved with the central agency, responsible for many tasks including system definition, systems development, supplier and user training and education, system operations, system maintenance, system review and revision. The role of the user should define the system. Theoretically, the user can define the data elements necessary to support the decision-making process. Yet this is often the source of the system's key problems. The user's needs are often very difficult to define and, realistically, can never be seen as complete or fixed. In practice, there are a great many data elements which are subject to change.

While the data user has difficulty trying to define the necessary elements, the supplier has difficulty trying to adjust his collection, submission and validation procedures in response to changing data requirements.

The operators' "non-systems" roles are often overlooked in the not-so-successful implementations of centralized systems. The responsibilities of this group, as outlined above, are far-reaching and essential to the success of the system. The common practice of attempting to coordinate and implement such systems utilizing only 'systems experts' often produces undesirable results. As we discuss later, of greater importance in the implementation of centralized systems will be this group's ability to involve the data users and suppliers in a cooperative systems development environment.

\section{Common Problems with Centralized Systems}

To be effective, centralized information systems must support the government's decisionmaking process. However, a number of common problems have often occurred with such systems. These problems include:

\section{Imprecise Data Definition}

Ambiguity of definition produces the following undesirable situations:

- similar data not being comparable because data suppliers have interpreted the same vague definitions differently;

- several requests for the same information since different users are not sure of the true meaning of information collected according to vague definition;

- delays while suppliers/users clarify ambiguous definitions and collect (or re-collect) the required data;

- questionable decisions and policies based on incorrect or misinterpreted data.

Unnecessary Complexity

Information systems seem to become increasingly larger and more complex and dominate, 
rather than support, the information flow between institutions and governments. (As we shall discuss later, such a situation occurred with the Ontario College/Ontario Government information flow.) Data collection and validation tend to become ends in themselves. This problem occurs when an information system includes information which is:

- obsolete: while the need for the information has disappeared the data is still collected and maintained;

- nice-to-know: while the information was not required it was included because someone identified it as something which 'might be nice to know';

- temporary: the data required for a special one-time study or research project were included in the system. (Normally this occurs when such a study coincides with system development or revision.);

- highly interdependent: the input being requested required extensive communication between the various operational sectors of the supplier institution. This type of input is often characterized by its ratio attributes, for example, square feet (physical facilities data) per full-time equivalent student (registration information). This type of information should be produced by the computer (centrally) from basic data collected independently in each department of the institution. Data suppliers should not handle tasks ideally suited to the computer.

\section{Unreliable Data Processing Service}

Often the computer is blamed for delays and other difficulties associated with information systems. The computer serves as a scapegoat for inadequate operator service in such areas as systems design, procedure development, user training, input/output handling. Such problems are characterized by:

- slow turnaround (the time between submission of data or information requests and generation of output reports);

- incorrect handling of data submission and report requests (often caused by poorlydefined or loosely administered procedures or poor user training);

- delays in identifying and correcting system 'bugs' (often caused by lack of good systems documentation and/or inadequate testing).

\section{Inadequate Training and Support Services}

Staff mobility in both institutions and government necessitates the training of new personnel to supply, operate and use information systems. Systems revisions also generate a need for retraining. Often suppliers and users of data have responsibilities, other than those related to the system, which take up the majority of their time. They accordingly require special support from the systems operators.

Inadequate training and support services can often be attributed to:

- incomplete, obsolete, or poorly-written documentation;

- low priority at the central agency (inadequate resource assignment to this activity);

- poor communication skills of systems operators (assignment of 'systems technologists' to the user education role);

- lack of awareness of supplier and user needs.

We believe that the problems we have outlined highlight the basic flaws which have occurred in the development of central information systems in the public sector. Namely, 
often there has been a lack of participation and ongoing coordination among the data suppliers, the system operators and the data users.

As a result, the centralized system, which should be seen as promoting institutional viability and accountability and as resulting in more effective governmental decisionmaking, is seen as an ineffectual, time-consuming exercise. The institutions ignore data submission schedules, impatient data users perform ad hoc surveys and decisions are made without important quantitative data. The resulting conflict between data suppliers, who feel the data being collected are not required or used, and the data users, who feel the suppliers are being tardy and/or imprecise, produces an environment which can naturally become hostile to systems. In such an environment, the systems operators, sandwiched between the data suppliers and users, tend to become indifferent to their responsibilities. In the end, the utility of the system deteriorates.

We feel that this situation can be alleviated or avoided if a participative approach is defined and used as the essential characteristic in the development, implementation and ongoing review of a centralized information system.

\section{ONTARIO BEFORE THE ONTARIO COLLEGE INFORMATION SYSTEM (OCIS)}

\section{The College/Government Structures}

In May 1965, the Ontario Government introduced legislation which provided for the establishment and operation of the Colleges of Applied Arts and Technology. These colleges were to be community colleges designed to meet local needs. They were given three main responsibilities: ${ }^{1}$ 1) to provide courses of types and levels beyond or not suited to the secondary school setting; 2 ) to be an alternative to university; and 3) to meet the educational needs of the adult and out-of-school youth whether or not they are secondary school graduates.

The major components of this college system are described below:

\section{The Colleges}

In 1967 the first of the Colleges of Applied Arts and Technology (CAAT's), Centennial College in Toronto, was officially opened. In 1977, only a decade later, the CAAT's have grown to the following dimensions:

- 22 separate colleges with over 90 campuses;

- approximately 12,000 full-time administrative and academic staff; ${ }^{2}$

- nearly 80,000 full-time students; ${ }^{3}$

- about 160,000 registrations in part-time courses in the fall; ${ }^{4}$

- over $\$ 340$ million annual operating budget; ${ }^{5}$

- an estimated $\$ 600$ million in capital assets. ${ }^{6}$

\section{The Boards of Governors}

Each of the 22 colleges is a crown agency governed by a local board of governors. Each board ensures

... the flexibility necessary for colleges of applied arts and technology to be able to respond effectively to community post-secondary and adult education needs. ...? The boards of governors are responsible for choosing the president who is the chief 
executive officer of each college. As chief executive officer, the president, assisted by the administrative officers of the college, is responsible for the day-to-day operation of each college:

\section{The Council of Regents}

While the board of governors at each college sets priorities at the local community level, system wide coordination for the CAAT's is performed by the Council of Regents:

The Minister shall be assisted in the planning, establishment and coordination of programs of instruction and services for such colleges by a council to be known as the Ontario Council of Regents for Colleges of Applied Arts and Technology, composed of such members as may be appointed by the Lieutenant Governor in Council. ${ }^{8}$

The Council of Regents is composed of a full-time chairman and up to 14 lay persons who serve a three-year term of office. This Council meets from two to three days each month.

The legislation which governs the 22 colleges:

. . provides for a tripartite division of responsibilities among the Minister of Colleges and Universities, the Council of Regents and college boards of governors. . . Initiative for developing college master educational plans, selection of appropriate sites, and introduction of new programs of instruction rests with individual college boards of governors. Approval to proceed according to these initiatives. . rests with the Minister. The requests reach the Minister via the Council of Regents, which assesses the merit of the requests in terms of provincial requirements, as well as local community need. The Council in turn recommends to the Minister approval, disapproval or modification of each individual college submission. ${ }^{9}$

\section{Ministry of Colleges and Universities}

The Ministry of Colleges and Universities is responsible for the day-to-day administration of central policies governing the 22 colleges.

The organization structure of the Ministry and its involvement in the Ontario College Information System is illustrated in Figure 2 which appears later in this article. Two of the three major divisions, the College Affairs and Manpower Training Division (policy) and the Common Services Division (service), are fairly involved with the administration and coordination of government policy related to the colleges.

\section{The Pre-OCIS Centralized Information Systems}

The rapid growth of the CAAT's made large demands on the planning and resource allocation capabilities of the Council of Regents, the Ministry, the college Boards of Governors and the college administrations. Legislatively, the Council of Regents had been identified as the prime planning agent for the college system. In cooperation with. the Ministry, the Council employed a private educational consulting company, Systems Research Group, to provide the technical expertise and project management skills in developing a planning model and a statistical information collection and reporting system. These systems were intended to serve both the colleges and the central agencies (the Ministry and the Council of Regents). 


\section{The CAMPUS System}

During the period 1969-1974 both a planning model and several statistical systems, collectively referred to as the CAMPUS System, were developed and continually updated. By 1974 the planning component of the system (referred to as CAMPUS VIII) dominated the planning exercise in the colleges and at the Ministry.

CAMPUS VIII was a resource requirement prediction model which had been developed initially at the University of Toronto. Using the logic illustrated in Figure 1, it forecast the demand for college resources, based on enrolment projections. This demand for the resources was then compared to the anticipated supply of resources to provide an estimate of future shortages or surpluses.

\section{System Problems}

Technically the CAMPUS VIII model was an effective planning tool, but its use resulted in two major types of difficulties:

\section{Application: It was designed for one purpose but primarily used for another}

Originally CAMPUS VIII was designed as an institutional planning tool. It was a researchoriented model to be used in support of educational policy and decision-making by indicating the resource requirements (funds, space, etc.,) associated with various institutional policies. However, during its implementation in the CAAT's, CAMPUS VIII was gradually expanded into a centralized reporting and planning system.

This conversion did not result from any conscious design change. Rather it occurred piecemeal as the reporting needs of the colleges and the central agencies (the Ministry and the Council of Regents) were altered and increased. The increase in the reporting needs accelerated during the development of the CAMPUS system and more and more data was provided to the central agencies via CAMPUS VIII add-ons.

The incremental conversion of this planning model into a centralized reporting system resulted in a much greater level of detail in both input and output data than would have been required for a planning/simulation model.

This problem of using a planning model as a reporting system was most apparent to the data supplier (the 22 colleges) and least apparent to the predominant user (the Ministry). As more and more data requirements were added by the user, the supplier of the data became almost totally involved with the collection and validation of data.

\section{Effort Involved: Data Collection and Validation in Lieu of Exploring Alternatives}

The purpose of a planning model is to assist in the evaluation of policy alternatives. Various policy alternatives should be simulated and the results compared and evaluated.

Each year every college prepared the information required to evaluate at least one alternative because the results of this evaluation were required as part of their annual planning submission (the Multi-Year Plan) to the Council of Regents. However, as a result of the large quantity of reporting and statistical information incorporated into CAMPUS VIII, simulating this one alternative was all many colleges did.

As an aid to effective planning, CAMPUS VIII should have been used to simulate not one but several alternatives. However, in many colleges this did not occur because the 


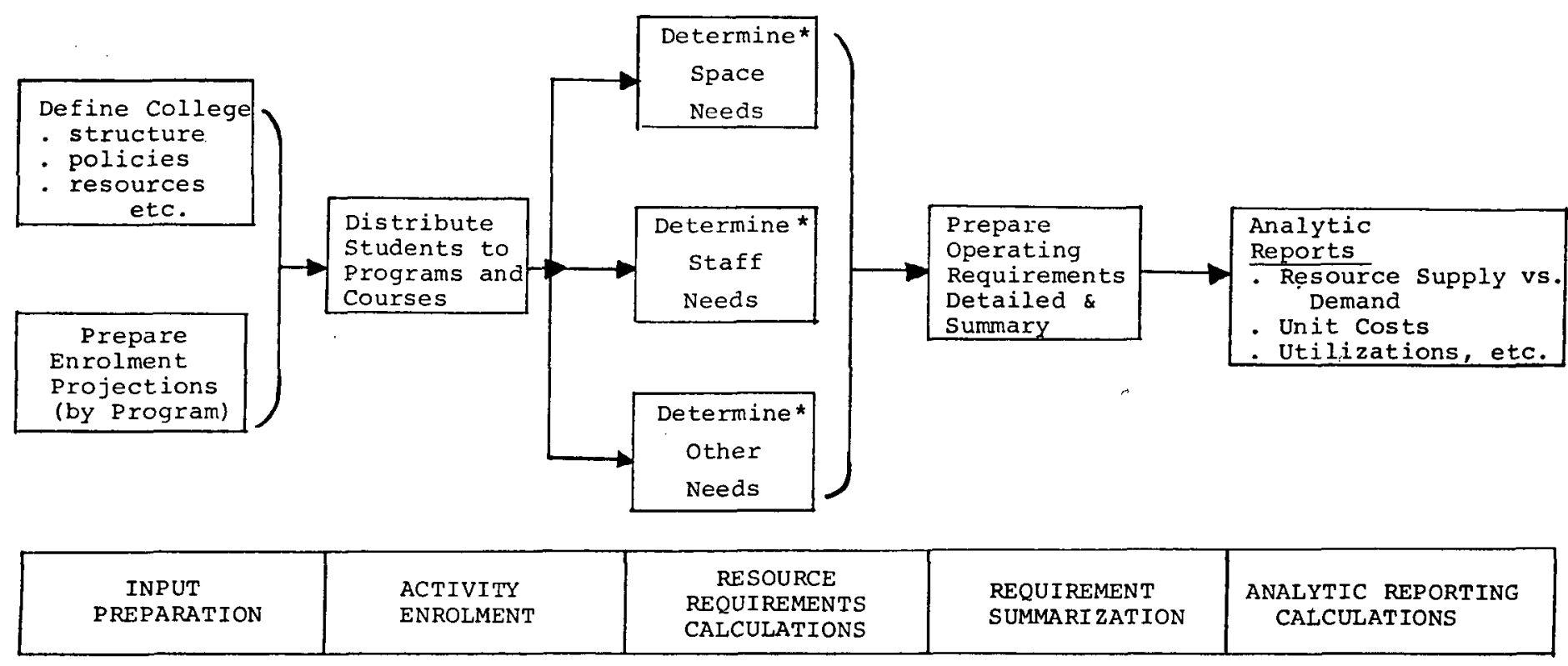

*By Resource relationship (college defined) which define resource needs in terms of numbers of students, sections, programs etc. 
manpower required to prepare the data essential to simulating each alternative appeared excessive.

To understand the magnitude of the data collection/validation task consider the following: the first step in using CAMPUS VIII was to create a base year which would illustrate the college's operating structure policies and act as information upon which projections (planning) would take place. For most colleges, using CAMPUS VIII involved the collection and validation of over 100,000 pieces of information on college structure, programs, students, staff, space, revenues, expenditures, budgets, etc. As a result of the nature and volume of data:

- a large number of professional consultants functioned in clerical capacities validating data;

- significant amounts of college and outside time were used in collection and validation tasks.

\section{System Benefits}

Despite the practical and conceptual problems, the CAMPUS system produced a number of significant results:

- it was instrumental in the development of the annual multi-year planning cycle at each college;

- it developed a basic discipline necessary for effective reporting and planning within a large public system;

- it acted as a catalyst in the development of internal college information systems;

- it created the basis of consistent system-wide comparative data and performance indices;

- it promoted a consistent language or terminology for College/Ministry planning and reporting.

In 1975, an independent study of the CAMPUS system and the experience with it in the Ontario college system was completed. ${ }^{10}$ As a result of this study, the Ministry decided to build on the experiences of the CAMPUS system and to develop a centralized information system which would provide the data required to satisfy the ongoing central information needs.

The centralized planning system - CAMPUS - was discontinued and replaced with a centralized information system. This change of focus encouraged more decentralized planning based on each college carrying out its local planning role within broad provincial policy guidelines.

This decision, which followed the 1975 independent study of the CAMPUS system, led to the development and implementation of its successor - the Ontario College Information System.

\section{THE PARTICIPATORY ASPECTS OF OCIS}

\section{The Establishment of the Participatory Structures}

The independent study of the CAMPUS system was completed in April 1975. It made a number of specific recommendations, the most important being that any follow-up to the study should be done with the full participation of the colleges and the Ministry. 
This recommendation of joint participation was fully accepted and in the spring of 1975 , two committees were formed - the Provincial Steering Committee on Planning and the Task Force on College Planning.

\section{The Provincial Steering Committee on Planning}

This group is composed of senior representatives including: the Chairman of the Council of Regents, the Assistant Deputy Minister of the College Affairs and Manpower Training Division, the Presidents of two colleges, the Director of the College Affairs Branch and the Chairman of the Task Force on College Planning.

The Provincial Steering Committee was formed to provide policy direction for the follow-up to the consultants' study of the CAMPUS system and to ensure that all relevant sectors of both the college and the central agencies were represented. All final decisions concerning the development and implementation of the Ontario College Information System are the responsibility of this group.

\section{The Task Force on College Planning}

The independent study had recommended that both Ministry and college personnel be used in the development and implementation of the successor to the CAMPUS system. In support of this recommendation, the Task Force on College Planning was formed at approximately the same time as the Provincial Steering Committee on Planning. The Task Force was responsible for the initial follow-up work, under the guidance of the Provincial Steering Committee.

The Task Force comprised full-time Ministry personnel as well as people seconded from the colleges on a part-time basis. The consultants' recommendation to second college members on a full-time basis was not deemed feasible because of the problems associated with relocating the senior college staff required for this Task Force.

From the outset, this Task Force was closely involved with the Provincial Steering Committee; the Task Force chairman served as the secretary of the Provincial Steering Committee.

\section{The Special Projects Office}

Several factors contributed to the formation of a third group which became important in the operating success of the Task Force and the development and implementation of OCIS. This group was the Special Projects Office.

During the period 1969-1975 the Ministry had used consultants to design, develop and maintain the CAMPUS system; as a result the Ministry had developed no in-depth technical knowledge of planning or statistical systems. To fill this void, several individuals with current expertise in computer-based planning and information systems were hired by the Ministry. These individuals, attached to the Special Projects Office, provided the day-to-day continuity for the work done by the Task Force.

As recommended by the consultants' report, this group reported directly to the Assistant Deputy Minister, College Affairs and Manpower Training. The staffing of this group developed slowly and specifically in response to the need for particular operational, technical, consulting and/or project management skills.

\section{Other Areas of Participation}

The Ontario College Information System was developed essentially to provide data for 
the Ministry and the Council of Regents. The structures outlined in the previous sections created the participatory environment. However, it is important to note that there were certain areas of the Ministry which were more involved than others with college information and thus with OCIS. These Ministry involvements were essentially of two kinds:

- "system" involvement where the group was involved with all parts of OCIS (for example system development);

- "component" involvement where the branch is involved with only a specific number of information components of OCIS.

The organization of the Ministry is illustrated in Figure 2. This chart also shows the following two important aspects of the Ministry's participatory involvement with OCIS:

- the reporting relationship of the two joint Ministry/College committees directly involved in the development of OCIS;

- those areas of the Ministry with either "system" involvement or "component" involvement with OCIS.

\section{The Various Levels of Participation}

We must stress that the groups mentioned above were created to ensure that all sectors of the colleges and the central agencies could participate in the step-by-step development and implementation of OCIS. One of the most persistent criticisms of the CAMPUS system by the colleges was that it had not been developed by the central agencies (the Council of Regents and the Ministry) but had been a "canned" system installed without a detailed study of its applicability to the Ontario college environment.

At the senior level of participation in the development of OCIS, that of the Provincial Steering Committee, all key constituencies of the CAAT system were represented. This group provided necessary initial credibility in the development of the new system.

The membership of the Task Force on College Planning reflected a conscious effort to get individuals from the colleges and the Ministry who were generally regarded as active leaders in the field of college planning. This pattern of selective use of staff was repeated several times as the Task Force engaged various individuals, particularly from the colleges, to help develop and review various components of OCIS. This concept was also applied in staffing the Special Projects Office.

It should be noted that the development of OCIS was structured to avoid having a "system's group" system. Rather the development of OCIS was based on the effective use of individuals in their recognized area(s) of expertise.

Participation: System Development and Implementation. As soon as the Provincial Steering Committee had reviewed the independent study of the CAMPUS system and approved the majority of the report's recommendations, it asked its working group, the Task Force, to develop a plan for the implementation of the successor to the CAMPUS system. Specifically the Provincial Steering Committee requested answers to two basic questions:

1. What is the nature of the college data required by the Ministry in order to perform its functions?

2. What data processing and reporting system(s) are appropriate to process this data? The task of answering the first question was completed by the fall of 1975 . To 
Figure 2

Apri1, 1977

A DIVISIONAL ORGANIZATION OF MINISTRY OF COLLEGES AND UNTVERSITIES

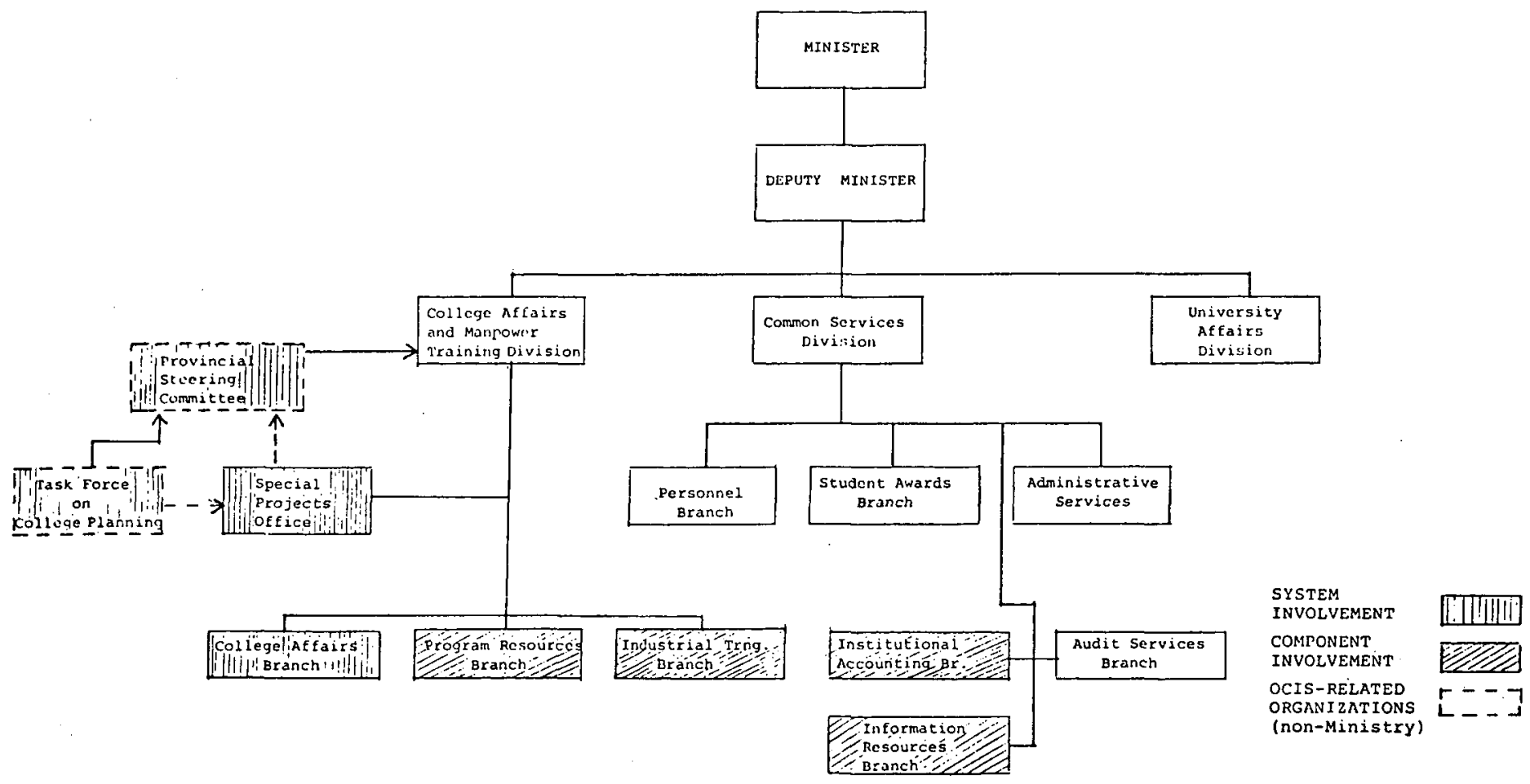


determine the nature of the data required by the Ministry, the Task Force:

- made a thorough study of the various processes within the Ministry which create a demand for data. Examination focused on what processes occur that create a demand for particular data and why/how does each process occur. The effect of processes outside the Ministry's jurisdiction which require data from the colleges, directly or indirectly, was also examined; for example, other provincial ministries and Statistics Canada.

- prepared a "Summary of Information Flow". This document was a compendium of samples of all reports and forms sent by a typical college to the Ministry during the previous year. This summary was reviewed to identify which requirements had been peculiar to that year, and which would be continued.

Having determined not only the nature of the information required by the Ministry but also the nature (and scope) of information collected by the Ministry, the Task Force reported the results of its study to the Provincial Steering Committee.

Before discussing the Task Force's findings and recommendations pertaining to answering the second question in their mandate, let us first consider the participatory aspects of the Task Force during this period.

The Task Force was formed initially with six members. Given that most of the members could only spend a small portion of their time on the important tasks that faced them, it was important that this time be productive. Initially there was no way of estimating what could be accomplished because of the following characteristics of the Task Force:

- it was small (six members);

- it was composed equally of two factions (the Ministry and the Colleges);

- the members lived and worked in several different cities;

- most of the members were part-time;

- there was a great deal of pressure to produce, in a short time, a system that was acceptable to the colleges;

- the members did not know one another well;

- each member was in the position of representing several strong and potentially conflicting interests;

- a healthy rivalry existed between college and Ministry personnel.

Fortunately, the initial task turned out to be a positive catalyst in developing an effective working relationship amongst the Task Force members. Often the colleges had accused the Ministry of demanding more information than was essential to their various needs; on the other hand, the Ministry had often expressed the need for greater accuracy in the reporting of college data. The members of the Task Force repeated this theme and its variations during their early meetings. As a result of these vigorous discussions, the college and Ministry staff each developed a healthy respect for the other's perception of this many-sided problem. Out of the countless variations of the theme of too much data and not enough accuracy, an effective accord between the members developed, an accord based on explicitly cutting the flow of data to that which had a demonstrated use while requiring a high level of accuracy in this reduced flow. A corollary to this accord was that not only would the data flow be reduced and made more accurate but the system used to store and analyze the data would be simplified and made more practical to the 
potential users than the previous system. This corollary all but answered the second question posed by the Provincial Steering Committee.

It must be stressed that a key element in the design and implementation of the Ontario College Information System was the trust and psychological accord developed among the members of the Task Force in dealing with the determination of the actual data needs of the Ministry. The members had, within their group, significant systems expertise and could have called on much more technical expertise; however, this expertise was of minor importance compared to the highly vocal, aggressive, participative environment which developed in the first few months of the Task Force's existence.

As mentioned previously, the answer to the Provincial Steering Committee's second question, "What data processing and reporting system(s) is appropriate to cope with the data?" flowed naturally as a result of the nature of the Task Force membership and its activities in the resolution of the first request of the Provincial Steering Committee.

In March 1976 the Task Force presented the Provincial Steering Committee with a list of assumptions (and their implications) concerning the characteristics of OCIS. These assumptions provided a comprehensive guildeline for the future development of OCIS. The assumptions (nine) and their implications are included as Table 1. ${ }^{11}$

TABLE I

ONTARIO COLLEGE INFORMATION SYSTEM

ASSUMPTIONS AND THEIR IMPLICATIONS

\begin{tabular}{|c|c|}
\hline ASSUMPTION & IMPLICATIONS \\
\hline $\begin{array}{l}\text { The Ontario College Information } \\
\text { system should satisfy information } \\
\text { needs of both the Ministry and } \\
\text { the Colleges. }\end{array}$ & $\begin{array}{l}\text { Groups impacted by the system } \\
\text { should have input to relevant } \\
\text { areas of the system design. } \\
\text { For example, the design of } \\
\text { the financial area of this } \\
\text { system should have input from: } \\
\text { - College Finance officers; } \\
\text { - Institutional Accounting Branch; } \\
\text { - College Affairs Division. } \\
\text { The College input is, in part, } \\
\text { being accomplished by: } \\
\text { - Task Force on College Planning } \\
\text { and Policy; } \\
\text { - Provincial steering Committee } \\
\text { on College Planning. }\end{array}$ \\
\hline $\begin{array}{l}\text { A major focus of the ocIs must } \\
\text { be accountability. }\end{array}$ & $\begin{array}{l}\text { The information in the system } \\
\text { must be of sufficient validity and } \\
\text { detail to: } \\
\text { - provide the taxpaying public } \\
\text { with pertinent information on }\end{array}$ \\
\hline
\end{tabular}


TABLE 1 (Continued)

\begin{tabular}{|c|c|}
\hline ASSUMPTION & IMPLICATIONS \\
\hline & $\begin{array}{l}\text { the educational operation they } \\
\text { are supporting. This is done } \\
\text { by both the colleges (locally) } \\
\text { and the Ministry (provincially); } \\
\text { - support the justification of } \\
\text { Eunds from the Ontario Treasury; } \\
\text { - support the college position } \\
\text { on the college/university } \\
\text { division of funds within the } \\
\text { Ministry; } \\
\text { support claims to the Federal } \\
\text { Government under the Fiscal } \\
\text { Cost sharing Agreements. }\end{array}$ \\
\hline $\begin{array}{l}\text { The OCIs must be conceptually } \\
\text { simple. }\end{array}$ & $\begin{array}{l}\text { Each component (subsystem) in } \\
\text { the ocIs must be easily under- } \\
\text { stood. Such understanding will: } \\
\text {-- minimize the college and - } \\
\text { Ministry user education require- } \\
\text { ments; } \\
\text {-- promote acceptability, espe- } \\
\text { cially with the 'peripheral } \\
\text { contact' user. This user } \\
\text { group, e.g.'deans, presidents, } \\
\text { found it difficult to under- } \\
\text { stand and thus use and/or } \\
\text { accept the previous planning } \\
\text { and reporting model. }\end{array}$ \\
\hline $\begin{array}{l}\text { The oCIS must be modular in } \\
\text { design. }\end{array}$ & $\begin{array}{l}\text { The system will consist of } \\
\text { operationally separate subsystems, } \\
\text { including those for: } \\
\text {-- financial; } \\
\text {-- staff; } \\
\text {-- physical facilities; } \\
\text {-- student; } \\
\text {-- curriculum; } \\
\text {-- enrolment. } \\
\text { Each component (subsystem) will } \\
\text { be implemented separately to } \\
\text { minimize disruptions and to } \\
\text { simplify user education. } \\
\text { (Note that the order of the } \\
\text { above subsystems does not imply } \\
\text { any implementation priority.) }\end{array}$ \\
\hline
\end{tabular}


TABLE 1 (Continued)

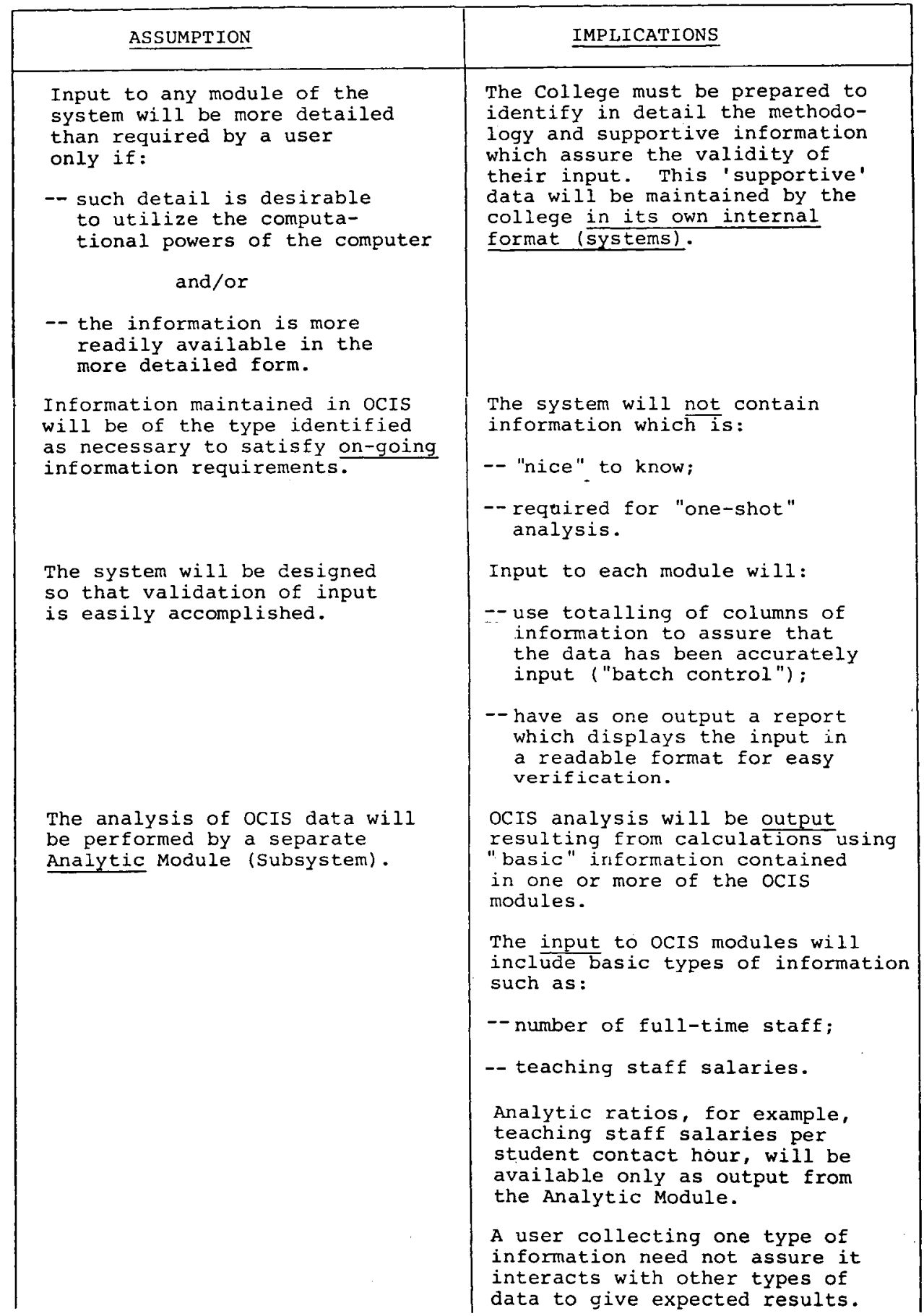


TABIE 1 (Continued)

\begin{tabular}{|l|l|}
\hline \multicolumn{1}{|c|}{ ASSUMPTION } & \multicolumn{1}{|c|}{ IMPLICATIONS } \\
\hline & $\begin{array}{l}\text { (Such interactions are a charact- } \\
\text { eristic of simulation models } \\
\text { such as CAMPU vIII) The user } \\
\text { need only verify it accurately } \\
\text { represents the situation in } \\
\text { his/her area. }\end{array}$ \\
$\begin{array}{l}\text { A major benefit of ocIs will be } \\
\text { the availability and distribution } \\
\text { Collegarable data from each }\end{array}$ & $\begin{array}{l}\text { The definitions for all input } \\
\text { to OcIs must be precise, under- } \\
\text { stood, and adhered to by all } \\
\text { people preparing ocIs input. }\end{array}$ \\
$\begin{array}{l}\text { The analytic output must be pre- } \\
\text { pared and distributed to College } \\
\text { and Ministry users on a regular } \\
\text { and timely basis. The timeliness } \\
\text { of accurate information is } \\
\text { essential to the planning } \\
\text { evaluation process by all user } \\
\text { groups. }\end{array}$ \\
\hline
\end{tabular}

\section{THE PRESENT STATE OF OCIS}

It is easy to theorize that a participatory approach is the most suitable for implementing a centralized information system in an environment similar to that of the Ontario College/ Ontario Government. Therefore we feel obligated to support our assertions about the success of participation in the development and review of centralized systems by discussing the present state of OCIS. In this section we will also outline some of the short-term advantages which have resulted during the two-year history of OCIS.

OCIS is a modular system, each module containing a specific type of information.

\section{The OCIS Student System}

One of the first tasks undertaken in the development of OCIS was the modification of the student statistical component of the CAMPUS system. A joint committee of college and Ministry staff undertook an exhaustive review of the existing student information requirements and presented their recommendations and findings. The system was then revised and made fully operational in the fall of 1976.

Presently the OCIS Student System contains background, academic, and graduate follow-up data on each full-time post-secondary student who has attended an Ontario college since 1971 (approximately 280,000 students). The system has information on about 60,000 students attending the colleges in the current (1976/77) year. (At present, it does not contain information on full-time students who are not full-time postsecondary; there are approximately 20,000 such students.) All this information is collected and validated by the colleges.

The usefulness of any system is demonstrated by the use of the information it contains. The OCIS Student System has had many uses and users including: 
- the Ministry, for enrolment trend analysis, system-wide comparisons between colleges, student body analysis (landed immigrants, foreign students, out-of-province students);

- the colleges, for determining what share of the post-secondary students in the area (in fact from each high school in the area) attended a college; attended their college;

- the Toronto Board of Education, for analyzing the high school entrants into college business courses;

- Placement Officers, for generation of employment statistics;

- consultants, doing Ministry and College studies.

The volume and accuracy of the OCIS Student System data, along with its flexible reporting capability, resulted in over 1,000 reports being requested in 1976 and over 2,000 in 1977.

\section{The OCIS Staff System}

A system with a similar evolutionary pattern to the Student System, the OCIS Staff System, was extensively modified in the fall of 1976. Many of these modifications resulted from recommendations (by a joint Ministry/College review committee) to collect data which would support the collective bargaining process in the colleges. In Ontario these collective agreements are negotiated centrally on behalf of the Council of Regents.

The OCIS Staff System contains information on all full-time staff who have been in the colleges since 1971. There are about 13,000 staff in the 1976/77 academic year. These staff are the academic as well as the administrative college employees.

While the research-oriented studies related to staff are much fewer in number than those related to students, this file has and will be used for such analyses as:

- the comparison of male to female employees in various categories, at various colleges, etc.;

- the analyses of faculty workloads and salaries in support of collective bargaining; The use of this data in the collective bargaining exercise should be stressed since salary-related expenses account for approximately $80 \%$ of college operating costs. We should emphasize the following facts about both the OCIS Student and Staff files:

- the contain the information required by Statistics Canada (and this is supplied annually by the Ministry);

- they contain no names and are number-referenced by the college to assure confidentiality of the data (since they contain data on individual students and staff);

- they are used to produce statistics on categories of students or staff, not individual students;

- they are "snapshot" files representing the college as of a specific date.

\section{The OCIS Physical Facilities System}

Information related to the physical facilities in the Ontario colleges is contained by two systems, namely:

- the OCIS Space System, a system which contains a room by room inventory of all college space which is owned or on a long-term (greater than one year) lease. For each room, the system contains the room category, subcategory, square footage, number of stations;

- the OCIS Capital System, a system which contains aggregate information on all 
approved capital projects. These projects go through several approval stages and aggregate information (square footage, costs, fees) is maintained by the system.

A review of these systems is commencing in May, 1977. Like the Student and Staff Systems, they contain information from 1971 to the present. (The Space System also contains projected data for buildings under construction.)

These systems were the last of the systems evolving from CAMPUS to be reviewed, for two main reasons:

- there has been minimal capital building since 1975 as college full-time enrolments are levelling out and capital funds are limited;

- the colleges were quite happy with the existing Space System; in fact, in the 1975 report, the consultants found that 16 of the 22 colleges would continue to use the Space System even if it was not required by the Ministry.

The physical facilities data is used by the colleges and Ministry for such analyses as:

- college comparisons on mix of space types, for example, classroom or other teaching space as a percentage of total space;

- unit comparisons between colleges, for example, student service space per full-time equivalent student, office space per full-time staff member;

- capital project expenditure monitoring.

\section{The OCIS Financial System}

The Provincial Steering Committee identified the reporting of financial data as a top priority. Therefore, the Task Force formed a Financial Group which was responsible for the development and implementation of a financial reporting system which:

- contained all financial data required by the Ministry on an ongoing basis;

- promoted meaningful and consistent inter-college comparison (by comprehensive definition of all elements);

- provided management information for the co!leges.

The Financial Group spent several months reviewing the needs for financial information in the Ministry and Colleges. Input was obtained from:

- Ministry branches, mainly College Affairs Branch and Institutional Accounting Branch;

- College Financial Officers;

- College Planning Officers;

- College committees including the Directors of Physical Plant;

- existing college and Ministry charts of accounts;

- the annual financial statements of the colleges;

- other educational systems.

A complete set of draft definitions was sent to the colleges and their comments were reviewed. These comments, which were obtained in writing, as well as the information discussed at regional meetings with college financial and planning staffs, were used in finalizing the financial element definitions. When the final definitions were then issued, they did not contain unexpected materials and were well received.

The financial system contains actual, budgeted and projected revenue and expenditure information for each college. Each year, four years of data - one actual, one budget and two projected - are input by the colleges. Systems input commences this year with fiscal $1976 / 77$ data being input to the OCIS Financial System. 
In making the system operational, clarification of a few definitions were required. However, the extensive care in review and development has resulted in a very small number of these operational clarifications.

While it is somewhat premature to list uses of a system which is just becoming operational, many potential uses of the financial data are possible. Uses will undoubtedly include:

- supporting funding requests to the Provincial Treasurer;

- supporting claims under cost-sharing agreements;

- analyzing expenditures (salary and fringe benefit) relating to the college bargaining units;

- undertaking types of costing, for example, academic costs per student, per graduate, college operating expenses per full-time equivalent student.

The design and implementation of the system was difficult, a situation compounded by previous experiences with the way CAMPUS processed financial data and a natural reluctance, by some, to have detailed financial data analyzed centrally.

The financial system illustrates another OCIS assumption; it permits a college, at its option, to input and analyze financial information at a greater level of detail than is compulsory. Colleges use this feature when:

- the information is more readily available in the less aggregate form;

- they choose to use an optional cost allocation feature of the system which is often suitable on a campus-by campus (other than college) basis;

- they plan on using the financial system's analytic capabilities and reports on subsets of their college.

It should be stressed that the participative environment has resulted in a financial system acceptable to data suppliers and users. This degree of mutual acceptance was satisfying and somewhat surprising in light of the sensitive nature of financial data.

\section{The OCIS Enrolment System}

While financial data may be most essential for demonstrating college accountability, information on its product, namely students, is also required. This information, on groups rather than individual students, is referred to as enrolment data.

In their decade of existence, the colleges have grown quickly in both numbers and types of students served. Arbitrary definitions of types of students have been developed during this period and they tend to produce confusing statistics since the definitions:

- often overlap certain groups of students;

- are inconsistently interpreted in the colleges and the Ministry;

- do not cover certain students.

A committee, working in a manner similar to the Financial Group, has reviewed the needs and problems associated with enrolment data currently available. This committee will be recommending the content of the enrolment information which is required, as well as the timing and systems involved in its collection.

\section{Other OCIS Systems}

Presently no other OCIS systems are in a review or development phase. The possibility of having a system containing curriculum information has been discussed. Its value will be 
re-assessed when the OCIS systems presently in development have been implemented.

The review of the existing and pending OCIS modular systems provides justification for asserting that OCIS has and will continue to work. The OCIS modular systems resulting from the participatory development have been based both on previous systems and newly developed systems. In both cases the participatory approach has resulted in:

- an increased awareness and appreciation of the user/supplier problems by the other party;

- a minimal amount of information flow - only what is needed and used;

- a smooth implementation as the data users and suppliers had advance knowledge of potential problems and benefits;

- usable operational information, for example, information which is consistently defined and collected in all colleges.

Another noteworthy characteristic has been that the cost of operating OCIS is less than $30 \%$ of the average annual cost of operating the CAMPUS system in the period from 1971 to 1975 .

\section{SUMMARY}

The participatory approach in the development of OCIS has produced a greater degree of user/supplier cooperation than was anticipated. The judicious choice of committee members, probably combined with some plain good luck, has produced acceptable OCIS systems.

The three principal groups appear to be having a favourable experience with OCIS:

- data suppliers find that their workload has decreased and that the information they are supplying is needed and used;

- data users are receiving information which is timely and usable;

- systems operators are not caught in the supplier/user sandwich and see increasing use being made of "their" systems.

Part of the reason for the experiences in Ontario must be attributed to the systematic participatory approach used in developing OCIS.

At this stage we judge the participatory approach to developing OCIS in Ontario to be a success since OCIS is meeting its objectives. Participation may not be appropriate for developing all systems of this type in the public sector, however, it has worked and is continuing to work in Ontario. We anticipate increasing long-term benefits, the natural result of data users, system operators and data suppliers working in a coordinated and cooperative fashion.

The views expressed in this article are those of the authors and not of the Ministry of Colleges and Universities or the Colleges of Applied Arts and Technology. 


\section{Footnotes}

1. From the statement by Hon. William G. Davis in the Legislature. 21 May 1965.

2. OCIS Staff File. April 1977.

3. OCIS Student File and other MCU Reports. April 1977.

4. MCU Enrolment Reports, April 1977.

5. This figure combines the grants for both post-secondary and federal O.T.A. funding for the $1977-78$ fiscal year.

6. Estimate based on MCU figures.

7. The Ontario Council of Regents for Colleges of Applied Arts and Technology, First Annual Report, p. 8 .

8. Ministry of Colleges and Universities Act, 1971 Section 6(2).

9. First Annual Report. p. 8.

10. "Planning and Statistical Systems for Colleges of Applied Arts and Technology", April 1975 Woods, Gordon and Co.

11. "Report of the Task Force/Planning Group to the Provincial Steering Committee on Planning", March 1976 